\title{
The Former Geiseltal Museum (1934-2011), the Eocene Geiseltal Fossilagerstätte (Germany) and the Scientific Meaning of Ben Barnes as a Pioneer of Systematic Quantitative Vertebrate Excavations in the Geiseltal Lignites \\ O Antigo Museu Geiseltal (1934-2011), a Fossilagerstätte Eocênica Geiseltal (Alemanha) e o Significado Científico de Ben Barnes como Pioneiro das Escavações Quantitativas Sistemáticas de Vertebrados nos Linhitos Geiseltal
}

\author{
Meinolf Hellmund ${ }^{\dagger}$ \\ Martin-Luther-Universität Halle-Wittenberg, Zentralmagazin Naturwissenschaftlicher Sammlungen, \\ Geiseltalsammlung, Domplatz 4, 06108, Halle, Saale, Germany. \\ $\dagger_{\text {in memoriam }}$ \\ E-mail: meinolf.hellmund@geo.uni-halle.de \\ Recebido em: 22/02/2017 Aprovado em: 20/02/2018 \\ DOI: http://dx.doi.org/10.11137/2018_1_108_119
}

\begin{abstract}
The Geiseltal was a productive area for mining of lignite (brown coal) for about 100 years in central Germany (state of Saxony-Anhalt). Recognition of the scientific value of its famous fossil content came about in the 1920s, and from the early 1930s onwards Geiseltal is known as a unique Eocene terrestrial/palustrial Fossillagerstätte. During your professorship and position as Head of the geological Institute in Halle (Saale) in the 1920s, he focused more and more on the famous and outstanding finds of fossils in the middle Eocene brown coal of the Geiseltal. Ben Barnes was the pioneer of systematic and quantitative vertebrate excavations in the Geiseltal lignites. With his successful work, undertaken using with modern scientific aspects of his time, he gave rise for many other researchers to do so in the same way and to contribute step by step in reconstructing the geological and palaeontological history of fauna, flora and palaeoenvironment etc. in the Geiseltal.
\end{abstract}

Keywords: Geiseltal; lignites; Eocene; Vertebrates

\section{Resumo}

Geiseltal foi uma área produtiva para mineração de linhito (carvão marrom) por cerca de 100 anos no centro da Alemanha (estado da Saxônia-Anhalt). O reconhecimento do valor científico do seu famoso conteúdo fossilífero se deu na década de 1920 e, desde o início dos anos 1930, Geiseltal é conhecida como uma fossillagerstätte eocênica gerada em condições terrestres/palustres. Durante a sua cátedra e posição como Chefe do Instituto Geológico em Halle (Saale) na década de 1920, Ben Barnes se concentrou cada vez mais nas descobertas famosas e notáveis de fósseis no meio do carvão marrom eocênico de Geiseltal. Ele foi pioneiro em escavações de vertebrados sistemáticos e quantitativos nos linhitos Geiseltal. Com o seu trabalho bem sucedido, realizado com os aspectos científicos modernos do seu tempo, formou muitos outros pesquisadores e contribuiu para a reconstrução da história geológica e paleontológica da fauna e flora de Geiseltal. Palavras-chave: Geiseltal; linhitos; Eoceno; Vertebrados 
The Former Geiseltal Museum (1934-2011), the Eocene Geiseltal Fossilagerstätte (Germany) and the Scientific Meaning of Ben Barnes as a Pioneer of Systematic Quantitative Vertebrate Excavations in the Geiseltal Lignites Meinolf Hellmund ${ }^{\dagger}$

\section{Introduction}

The Geiseltal was a productive area for mining of lignite (brown coal) for about 100 years in central Germany (state of Saxony-Anhalt). During the 19th century, lignite was excavated under-ground whereas during the 20th century one began mining in open pits. From 1861-1992, miners excavated 1,430 billion tons of lignite. Recognition of the scientific value of its famous fossil content came about in the 1920s, and from the early 1930s onwards Geiseltal is known as a unique Eocene terrestrial/palustrial Fossillagerstätte. Brown coal mining ended in 1993, and for the last 10 years the entire area has been covered by water, forming an artificial lake called the Geiseltalsee (Geiseltal Lake). Only a small part of autochthonous lignite is visible in an outcrop on the southern bank of the lake. The outcrop is protected by the state geological authorities as a scientifically important "geotope" situated close to the city of Halle (Saale).

\section{The Former Geiseltalmuseum (1934-2011) and its Vertebrate Fossil Collection}

Prof. Dr. Johannes Weigelt (1890-1948) founded the Geiseltal Museum of Martin-LutherUniversity Halle-Wittenberg (MLU) to display fossil finds from Geiseltal to the public and to create a place for their scientific study (Figure 1). Weigelt held the position of Head of the Museum as well as the director of the Geological and Palaeontological Institute. The Geiseltal Museum was open to the public for 77 years, only interrupted during World War II (Krumbiegel \& Hellmund, 2012).

Due to reorganization of the university, ownership of the collection moved in 2009 to the newly founded Zentralmagazin Naturwissenschaftlicher Sammlungen (Center for Natural Science Collections), but it is still part of Martin Luther University.

Plans to move the collection to a new location have been in flux. The thousands of specimens housed

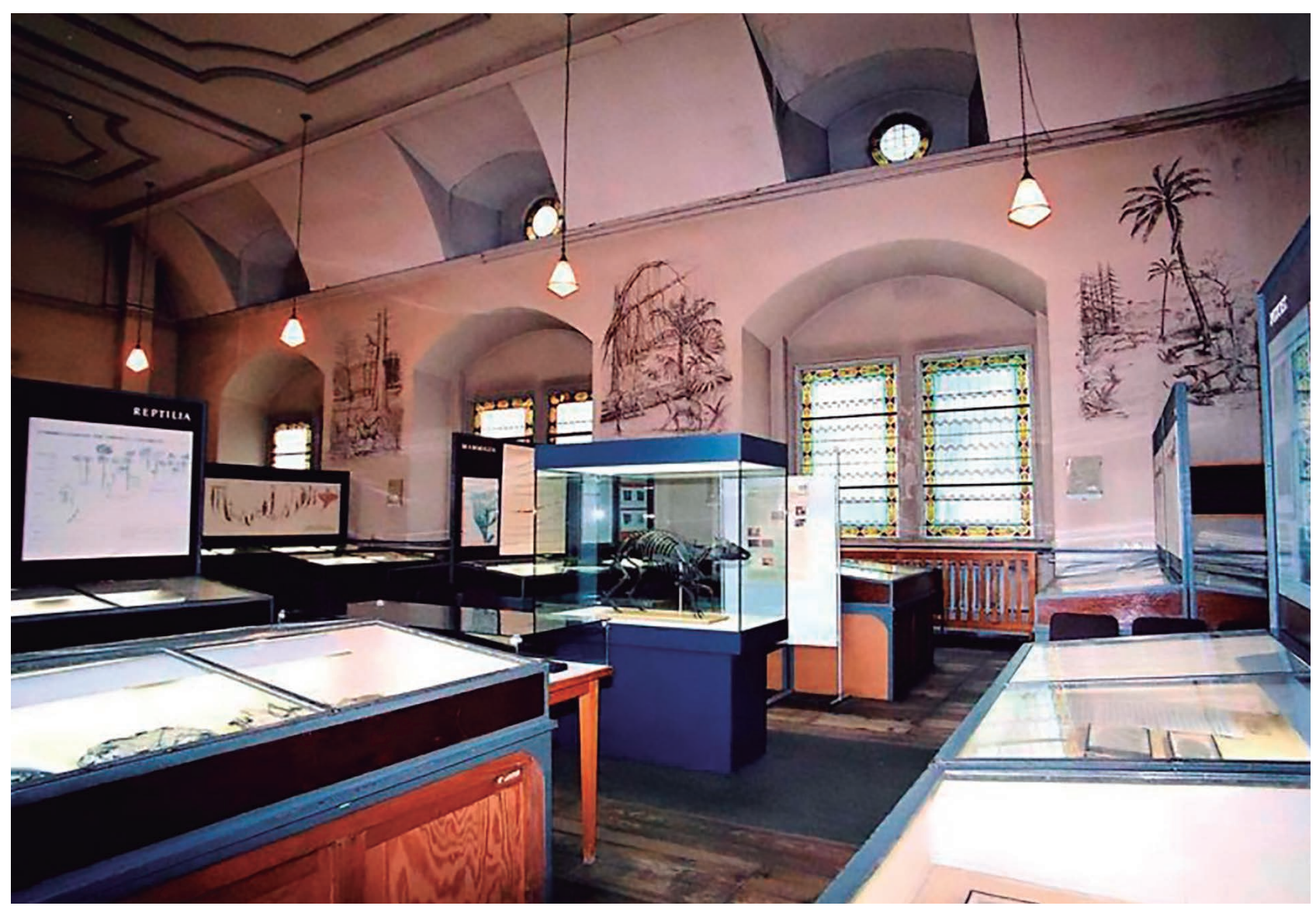

Figure 1 View into the permanent exhibition of the Geiseltalmuseum of Martin-Luther-Universität in Halle (Saale) in 2006 (Archive Geiseltalmuseum, ZNS). 
at the Geiseltalsammlung, especially vertebrate fossils, were collected over several decades and over many excavation efforts. From the beginning, in the middle of the 1920s onwards these excavations were conducted methodically and quantitatively (Barnes, 1927). Barnes was a pioneer of the excavations in the lignites and he brought a very nice collection of vertebrates, especially reptiles but also dentitions of mammals to light.

Further results of their careful documentation were published by Walther \& Weigelt (1932) and Weigelt $(1933,1934)$. In the following years, contributions have come from a number of multidisciplinary scientists. The excavation campaigns and research led to a representative overview of the Geiseltal vertebrate taxa in the permanent exhibition (e.g. Krumbiegel, 1959a, 1959b, 1962; Krumbiegel et al., 1983; Haubold, 1995).

The number of vertebrate sites and fossil finds decreased notably in the 1980s. In these mined pits differing geochemical parameters led to poorer fossil preservation. The stratigraphic sequence at Geiseltal consists of brown coal seams with intercalated clastics spanning from so called "Mammal Paleogene (MP) Zones 11 to 14" (lower Middle Eocene to lowermost Upper Eocene). For further information regarding biostratigraphy, see Schmidt-Kittler (1987) and Aguilar et al. (1997). The Geiseltal Fossillagerstätte yielded many excellently preserved mammalian fossils, qualifying it as a stratigraphically important locality for the terrestrial Middle Eocene of Europe. The importance of the site is due in part to some of the taxa described for the first time from Geiseltal (e.g. Barnes first described and named two species of snakes, Palaeopython ceciliensis and Paleryx spinifer in 1927).

Increased research interest in Geiseltal especially since the beginning of the 1990s has made its importance and relevance to Eocene chronostratigraphy more and more apparent. Geiseltal stratigraphic sections and their corresponding fossil mammals were used as references for the creation of MP Zones (see above) and for correlations with other terrestrial stratigraphic units of the Middle Eocene in Europe. For this reason, the European Land Mammal Age of this time is called the Geiseltalian (Franzen \& Haubold 1986b; Haubold 1987). Geiseltal sections were again used as reference in the formation of European Land Mammal Mega Zones (ELMMZ)
(Steininger, 1999). The Geiseltal fauna has been further utilized to verify theories of vertebrate palaeobiogeography and migration (e.g. Gastornis geiselensis, Hyrachyus minimus, Plagiolophus cartieri and Eurotamandua joresi). Cataloging within the collection's electronic data base is still ongoing, so that the total number is actually open. But the collection is known to include at least 30,000 vertebrate fossils ranging from isolated teeth, bones, jaws, skulls, to partial and complete articulated skeletons. So far 125 different species of vertebrates are recorded from the Geiseltal profile (newly updated by Hellmund \& Hastings (2014, table 1) in Smith et al. (2014). In addition to vertebrates, the site also includes many palaeobotanical fossils (e.g. spores, pollen, leaves, seeds, fruits, etc.), which have been scientifically treated and are housed mainly in the Museum für Naturkunde (Natural History Museum) in Berlin, Germany.

A synoptic view of the vertebrate taxa described thus far from the Geiseltal Fossillagerstätte was first published by Haubold \& Krumbiegel (1984), followed by Haubold (1995), Hellmund (2007), Hellmund \& Hastings (2014). These fossil objects were excavated and collected during two extensive field campaigns, one from 1925-1938, including Barnes's activities (1925 -1926) and the second from 1949 to the beginning of the 1980s. In the subsequent period, up to 1993 , active mining moved to the western and northwestern part of the open mines (Hellmund, 1997). Due to the unfavorable geochemical circumstances existing in this area during Tertiary time, only a few vertebrate fossils were found there (Krumbiegel et al., 1983; Hellmund, 1997).

\section{The Geological Age of the Geiseltal Vertebrate Fauna, Correlations with the Messel and Eckfeld Fossil Sites in Germany}

The Geiseltal lignite deposit formed ca. 4843 mya in the Middle Eocene and lowermost Upper Eocene under paratropical climatic conditions. This sequence consists of four fossiliferous lignite layers: the Unterkohle (Lower Coal), the untere Mittelkohle (lower Middle Coal), Obere Mittelkohle (Upper Middle Coal), and the Oberkohle (Upper Coal). The underlying Basiskohle (Basal Coal; uppermost Lower Eocene) is not fossiliferous. The 
Oberkohle yielded only one fossil vertebrate site, which is of basal Upper Eocene age. The lignite seams with their intercalated clastics cover a total of four stratigraphic terrestrial Mammal Paleogene Zones (MP 11-MP 14). Each represents a distinct mammalian fauna with a particular evolutionary stage (Schmidt-Kittler, 1987; Aguilar et al., 1997). The Geiseltal Fossillagerstätte, in contrast to other correlated sites (Messel and Eckfeld), displays a more or less continuous sequence of brown coal seams and clastic layers at this one location. The stratigraphic profile of the Geiseltal lignite deposit has a total thickness of ca. $120 \mathrm{~m}$. This fact enabled stratophaenetic investigations of vertebrate taxa under tightly controlled geologic parameters within the profile. Therefore, the Geiseltal Fossillagerstätte was chosen as a reference locality for MP 11-13 during two separate Palaeogene stratigraphic conferences. Although the Messel fossil site is a member of the UNESCO World Heritage list, it is not a reference locality for the lower Middle Eocene, following Schmidt-Kittler (1987) and Aguilar et al. (1997). The mammalian fauna of Messel corresponds to MP 11, the earliest stage represented at Geiseltal, equivalent with the Unterkohle layer. The small differences between the faunal content of the Geiseltal-Unterkohle and the Messel locality are likely due to their different geologic and palaeoecologic settings. Some difference may be also due to taphonomy or even methods of fossil excavation. A younger terrestrial Middle Eocene Fossillagerstätte can be found at Eckfeld, in western Germany, representing a single MP Zone (MP 13). Eckfeld corresponds with the Obere Mittelkohle layer at Geiseltal. Radiometric data are available from both Messel and Eckfeld, from igneous rock beneath these fossil deposits. Messel has been dated to $47.8 \pm 0.2 \mathrm{My}$ (Mertz \& Renne, 2005) and Eckfeld has been dated to $44.3 \pm 0.4 \mathrm{Ma}$ (Mertz et al., 2000).

Because of the different geologic setting, the Geiseltal site does not have the necessary rock type for radiometric dating. Combining these radiometric dates with biochronostratigraphic estimations of time based on evolutionary change yields a time span for the Geiseltal sequence of five to six million years. The framework of Mammal Paleogene (MP) Zones was first established during an international conference in 1987, held in Mainz, Germany (Schmidt-Kittler, 1987). During this meeting and a subsequent conference in Montpellier (France) in
1997, Geiseltal was used as reference localities for three consecutive MP Zones (Aguilar et al., 1997). The MP Zone concept is based on a sequence of locally restricted mammalian reference faunas, representing a certain evolutionary stage and by taxonomic first and last occurrences. The main advantage of the Geiseltal site for this purpose is that the sequence displays a nearly continuous profile at a single location, from the Middle Eocene to the base of the lowermost Upper Eocene. For this reason, biostratigraphers selected the Geiseltal Unterkohle through the Obere Mittelkohle layers as reference localities for the standard levels MP 11-13. Furthermore, the European Land Mammal Age called the "Geiseltalian" was simultaneously introduced (Franzen \& Haubold, 1987), characterized by a particular mammalian assemblage.

\section{Geologic Setting and Development of the Geiseltal}

The geologic development of the underlying Geiseltal basin was first formed 260 million years ago by the Late Palaeozoic Zechstein Formation, an Upper Permian layer containing halite and anhydrite. Later deposition of the Lower Triassic Buntsandstein (sandstone) and Middle Triassic Muschelkalk (marine limestone) forms the rest of the basin. A 140 million year hiatus follows, spanning the Upper Triassic (Keuper) through Cretaceous. Evidently a mix of geologic processes resulted in the loss or lack of deposition from this lengthy period of time. These may have included halokinesis (salt migration), erosion, tectonic epirogenesis, and subrosion of Zechstein rock and the red Upper Buntsandstein. Together, these phenomena seem to be responsible for the origin of the Geiseltal basin and allowed for the natural growth of peat bogs during the Eocene. Thick vegetation grew in the stagnant waters due to the soil formed from the underlying uppermost Buntsandstein. During the Eocene, central Europe had a paratropical climate, with many fens, swamps, ponds, and creeks across the landscape. This abundance of water and life led to an enormous buildup of organic matter in the former Geiseltal. The environment also led to an economically viable lignite deposit and the necessary circumstances for preservation of a scientifically significant Middle Eocene Fossillagerstätte. 
Regarding the Geiseltal Fossillagerstätte, Stanley (2001, p. 569) stated:

\begin{abstract}
"The most remarkable terrestrial faunas of the European Eocene - and perhaps of the entire Phanerozoic record - are found in the lignites, or brown coals, of the Geisel Valley in Germany."
\end{abstract}

Favorable geochemical conditions were not present throughout the Geiseltal coal seams, and as result fossiliferous areas were often concentrated into preservation zones. The rare circumstances of fossilization at Geiseltal can be explained by the inflow of calcareous waters from natural springs within the Muschelkalk limestone uphill to the south and southwest of the Geiseltal basin. The calcareous waters acted as a natural buffer, neutralizing the humic acids, tannins, and other aggressive solutes caused by diagenesis during lignite formation. This resulted in preservation of material that would have not been fossilized otherwise (e.g. Gallwitz, 1955; Krumbiegel, 1977). In addition, tanning and silicification led to precise structural preservation of soft tissues such as muscle fibers, feathers, and gut contents (Hellmund \& Wilde, 2009; Wilde \& Hellmund, 2010). These delicate tissues were excavated, preserved, and studied thanks to the laquer-film method of the late Voigt (1933, 1934, 1936, 1988).

\section{Modes of Fossilization and Preservation at Geiseltal}

The paratropical greenhouse environment of Geiseltal 45 million years ago consisted of peat bogs, swamps, ponds, creeks and dense jungle-like areas, south west of modern day Halle (Saale). The ecosystem supported high biodiversity, with 125 different vertebrate species. In addition to vertebrates, the Geiseltal Collection includes an impressive archive of fossil invertebrates and fossil plants. From the earliest excavations with the university, the Geiseltal site has been a focus of research also on the taphonomy of vertebrate carcasses and other dead organisms, initiated by Weigelt (1927, translated to English in 1989). Weigelt studied recent carcasses and applied the knowledge and methods he learned to the Geiseltal fossils in order to better understand what happened to carcasses from the point of death to the point of burial. At Geiseltal, Weigelt was able to see many of the same circumstances he documented while working at Smithers Lake (Texas, USA), which served as his "actuolab" (Hellmund, 2004). In general, three different types of fossil vertebrate sites can be distinguished at Geiseltal (Krumbiegel, 1977). The first type is essentially a circular sinkhole, caused by the erosion of evaporite-like sediments beneath the basin, which were subsequently filled with water. These sinkholes likely served as watering holes for the local fauna and even as natural traps, resulting in the accumulation of vertebrate carcasses. A second very prominent type of vertebrate site is the "Leichenfeld", a term that does not readily translate into English, but means roughly 'dying field' or 'corpse field'. The term was introduced by J. Weigelt (1927, translated in 1989) based on observations he made of modern carcasses at Smithers Lake in Texas, before he took his post in Halle (Saale) at the end of the 1920s (Hellmund, 2004). At the beginning of the 1930s he applied the results of his extant research to the concentrations of fossil vertebrates found within certain locally restricted areas of lignite seams. These "Leichenfeld" sites seemed closely connected with a certain facies, relating to their particular peat bog formation within the unit called the Oberes Hauptmittel (top of the layer called the Obere Mittelkohle, MP 13). The environmental parameters evidently changed following this deposition to dryer and colder conditions, and the ratio of organic accumulation (sedentation) dropped simultaneously. A third type of fossil site is referred to as "creeks". This preservation concerns former rivers flowing from the west or southwest into the Geiseltal basin. Just as with the sinkholes, concentrations of carcasses may also have gathered on or near the stream banks. In this scenario, animals may have become trapped while crossing the muddy substrate. Trapped animals may have subsequently fallen prey to crocodiles or other predators. In the early 1930s, Ehrhard Voigt (1905-2004), one of the founders of Geiseltal research, developed two new preparation methods for collecting fragile fossils. Both methods involve the transfer of fossils from the original lignite substrate to an artificial substrate. One method uses paraffin wax as the artificial substrate, and the other uses a translucent nitrocellulose lacquer. Application of these methods results in the reverse side of the 
fossil being exposed. This method avoids fossil disintegration and allows for articulated finds to be collected with their original position intact (e.g. Voigt, 1933, 1934, 1936, 1988). In the case of the lacquer film, the material would be brushed onto the surface of the fossil and surrounding matrix, then peeled off in one piece. This 'peel' preserved the fossil on a translucent artificial background, and in the case of small skeletons (e.g. fish and frogs) could be viewed with a microscope without further preparation. Instead of nitrocellulose lacquer, different sorts of epoxy resins are in use today, including fossils excavated at the Messel fossil site since the early 1970s (e.g. Wilde \& Hellmund, 2006).

\section{The Current Scientific}

\section{State of the Geiseltal Fossillagerstätte}

In the past 20-25 years, several orders of fossil mammals from the Geiseltal Fossillagerstätte have received rigorous study (e.g. ungulates: artiodactyls and perissodactyls), as well as their connection to other terrestrial Middle Eocene deposits in Europe, particularly Messel (e.g. Erfurt \& Haubold, 1989). New results were achieved in the systematics, stratigraphy, and palaeobiology of these animals (e.g. Franzen \& Haubold, 1986a; Franzen, 1995; Hellmund, 2000; Hellmund \& Koehn, 2000; Hellmund \& Wilde, 2009; Wilde \& Hellmund, 2010; Hellmund, 2013a, 2013b). Geiseltal and Messel are similar in many ways and complement each other well, despite having different geologic settings.

One of the more recent additions to the exhibits of the former Geiseltalmuseum was a lifesized three-dimensional reconstructed skeleton of the perissodactyl Propalaeotherium hassiacum, which is the result of an in-depth anatomical study (Hellmund \& Koehn, 2000; Koehn \& Hellmund, 2001). Similar work produced a model skeleton of the artiodactyl Amphiragatherium weigelti (Erfurt 2000), also

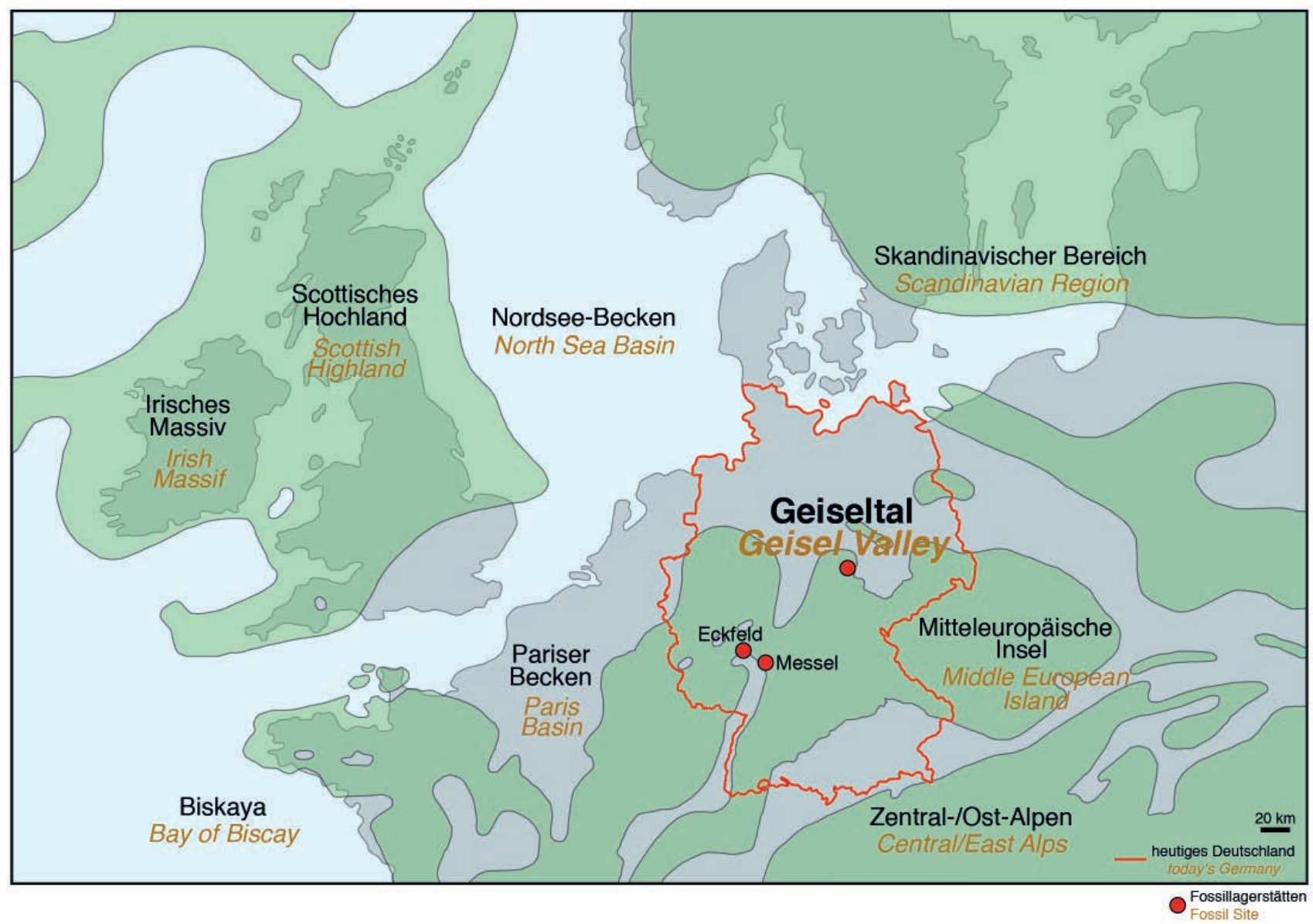

Figure 2 Eocene palaeogeographic map with Geiseltal location, outline of today's Germany (modified from Storch, 1986, and Hastings \& Hellmund, 2015). 
featured in the Geiseltal exhibit. The lophiodontids (presumably extinct relatives of tapirs/rhinos) are the largest mammals at Geiseltal, with a height of one meter at the withers and at least two meters in total body length. They are well represented within the collection by teeth, bones, and partially articulated skeletons. Surprisingly, only two lophiodontid specimens are known from Messel, a juvenile skeleton and an isolated premolar. A monographic account is ongoing for the lophiodontids as well as their relatives, the helaletids, including material from Geiseltal and other European localities. Other mammalian groups have received attention, including a study of the carnivorous Creodonta and Carnivora (Lange-Badre \& Haubold, 1990), niche partitions in Creodonta (Morlo, 1999), a monograph of the Geiseltal primates (Thalmann, 1994), and several orders of micromammals (e.g. Rodentia, Chiroptera, and some Marsupialia; Storch, 1995; Kurz, 2002, 2005). As for reptiles, studies from the last 20 years have focused on the crocodylians (Rauhe \& Rossmann, 1995; Rossmann, 2000b; Brochu, 2013), and lizards (Rossmann, 2000a; Müller, 2001; Rieppel et al., 2007). Studies of the Geiseltal crocodylians have revealed the first and only in situ record of a parent fossil crocodylian with eggs (Hastings \& Hellmund, 2015b). Additional skull shape analysis has shown the high diversity of crocodylian genera at Geiseltal is likely due to prey preference partioning. The avifauna of Geiseltal has been recently studied for its small birds (Mayr, 2002) and a revision of what was originally described as a vulture and hornbill from the 1930s (Mayr, 2007). A recent inventory was collected and published on the giant flightless bird Gastornis (Diatryma) for Geiseltal, which is the richest collection of this taxon within all of Europe (Hellmund, 2013b). Recent study of stable isotopes from Gastornis have revealed that its diet was herbivorous and that it is not the carnivorous terror bird that it was once thought to have been. Only the amphibians (except for some specimens) and snakes are in need of reinterpretation in terms of recent finds at other Eocene sites. Three-dimensional skeletal reconstructions of Gastornis and the crocodylian Boverisuchus in natural size were recently completed for a public exhibit in Halle (Saale) in March, 2015 (Hastings \& Hellmund, 2015a).

An international group of geoscientists began the "Geiseltal-Project 2000", which focused on palynology, stratigraphy, geochemistry, and petrography of Geiseltal lignite. The group worked with biomarkers including ferns, gastroliths, and resins (called "Affenhaar") from rubber plants (Hellmund \& Wilde, 2001). This project worked at the pit "Mücheln-Westfeld", where no vertebrate remains were recovered due to the deficiency of suitable geochemical parameters. Only the presence of crocodylians could be inferred from this area due to the recovery of fossil gastroliths (Hellmund, 2001). Following this project, geologic profiles were collected from 2001-2003 in the abandoned open pit "Neumark-Nord", within the upper Mittelkohle layer (MP 13). These were collected using the classic lacquer method described above for fossil extraction (Wilde \& Hellmund, 2006). The last fossil excavations efforts were conducted in the early 1990 s in the open pit named "Mücheln-SüdfeldFortsetzung" (Figure 3) belonging to the obere Mittelkohle Formation (MP 13, uppermost Middle Eocene). This collecting effort produced remains of some vertebrates, although not very spectacular, which are detailed by Hellmund (1997).

Further multidisciplinary investigations were conducted on a remaining coal seam in a more westward open pit, "Mücheln-Westfeld", which was organized in the early summer of 2000 (Hellmund \& Wilde, 2001). However, this expedition did not yield any vertebrate fossils.

In 2012, the entire Geiseltal Collection became an official member of the list for 'National wertvolles Kulturgut' (National Cultural Value and Heritage) and as a result it is now under government protection (Steinheimer et al., 2012).

\section{Concluding Remarks on the Geiseltal Fossillagerstätte}

The Geiseltal Fossillagerstätte is a site of phenomenal preservation of Middle to Upper Eocene fossils. The rare geochemical setting allowed for three-dimensional articulated specimens to be extracted and preserved at the Geiseltal Collection thanks to methods developed during early excavations in the 1930s. The oldest levels of Geiseltal correspond to the Messel fauna (MP 11), but continue in an unbroken sequence through correlation with the Eckfeld fauna (MP 13) and 


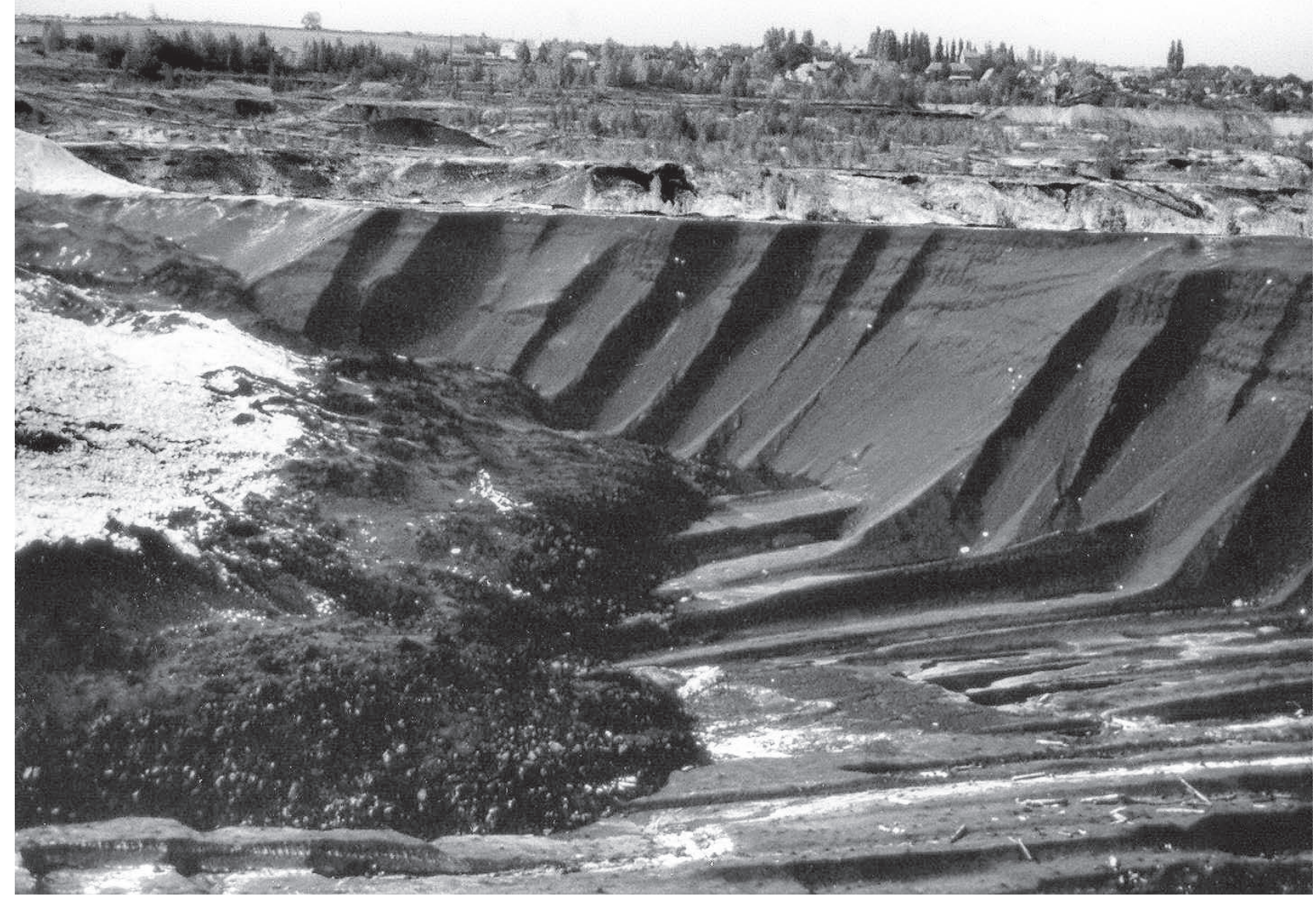

Figure 3 The last excavated vertebrate site in the "Mücheln-Südfeld-Fortsetzung" (Geiseltal-pit, upper middle Eocene coal seam), September 1992 (M. Hellmund, Geiseltal collection).

beyond for a total of five to six million years. As a result of this continuous record, Geiseltal fauna have been used as reference sites for MP Zones 11 through 13 , and was chosen as reference for the European Land Mammal Age, the Geiseltalian. 125 vertebrate taxa are currently recognized, but continued work will help to improve understanding of this incredible ancient fauna. The Geiseltal Collection houses thousands of fossils from this locality. Although it is not open to the public, it is open for scientific study.

\section{The Scientific Meaning of Ben Barnes as a Pioneer of Systematic, Quantitative Vertebrate Excavations in the Geiseltal Lignites}

During Prof. Dr. Johannes Walther's professorship and position as Head of the geological Institute in Halle (Saale) in the 1920s (Figures 4, 5 ), he focused more and more on the famous and outstanding finds of fossils in the middle Eocene brown coal of the Geiseltal. But he himself did not directly involve and participate in the Geiseltal research. Rare publications in this respect are usually in common with a coauthor.

The chronology of fossil vertebrate occurrences starts in the Geiseltal of the 20th century generally with scarce remains e.g. of a Lophiodon, an ungulate mammal, found in 1908, within Cecilie pit (Vetter, 1931; 1932, p. 29). This specimen was handed out to the Geological Institute in Halle (Saale) (see Barnes, 1927, p. 18). Salzmann collected further fossils of Lophiodon and turtles around the year 1912 [all finds are missing] (Vetter, 1931, 1932, p. 30).

An unknown miner discovered bones from a turtle in 1925, which were communicated to the Geological Institute in Halle (Saale) (Vetter, 1931, 1932, p. 31). 


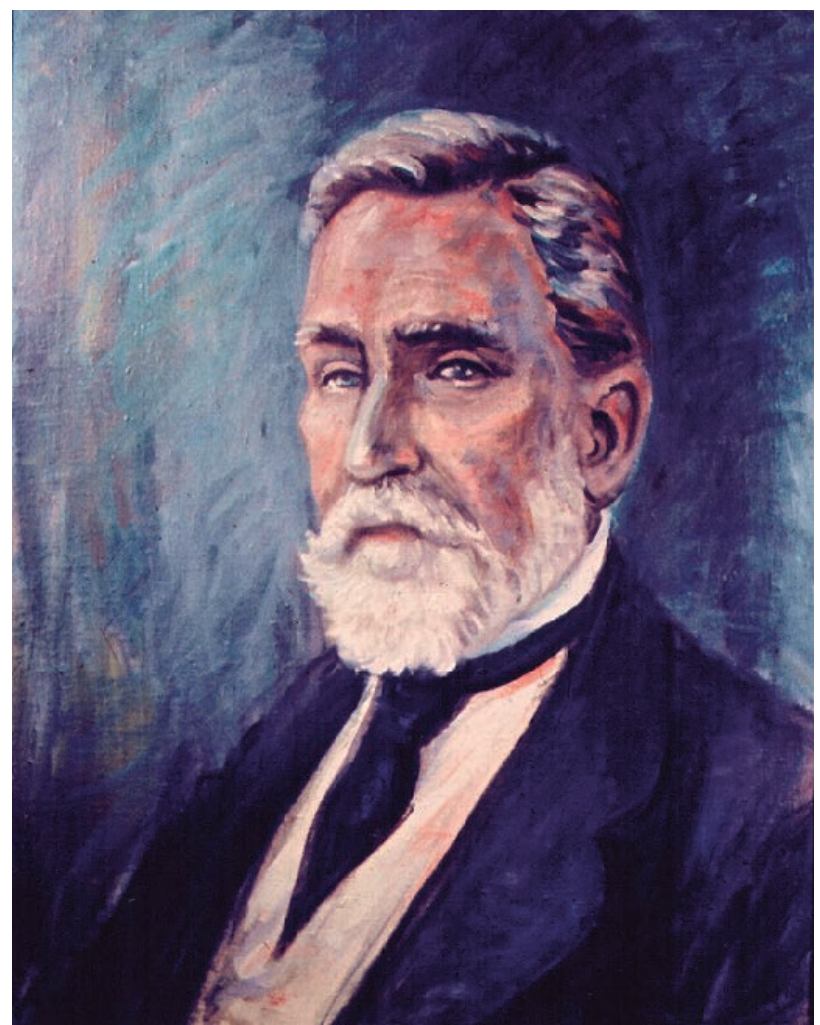

Figure 4 Painting of Prof. Dr. Johannes Walther (1860-1937), as President of the German Academy of Natural Scientists Leopoldina, owned by Archive "Deutsche Akademie der Naturforscher Leopoldina"; today: National Academy of Sciences, with residence in Halle (Saale). Prof. Dr. J. Walther was the scientific supervisor of Ben Barnes, when he worked in the Geiseltal "Cecilie pit" preparing his doctoral thesis.

This information was exciting and decisive enough for Walther and he supposed that there might be further fossiliferous sites nearby (see Barnes, 1927).

He subsequently asked Ben Barnes and offered him facilities for undertaking a detailed systematic excavation, for the very first time in the so called Cecilie pit, with a focus on Eocene fossil vertebrates. This excavation, in contrast to others, should be done with a quantitative background, meaning the interest was not only directed on brilliant finds to be exhibited later, but also in less preserved specimens to gather as most as possible informations on these former faunas. The field campaign started in spring 1926 and in a comparatively short time a little, but impressive fauna of fossil vertebrates came to light (Vetter, 1931).

Snakes, turtles, teeth and bones from different ungulates were thoroughly documented, both in text explanations and in three nice plates (Barnes, 1927; Figure 6).

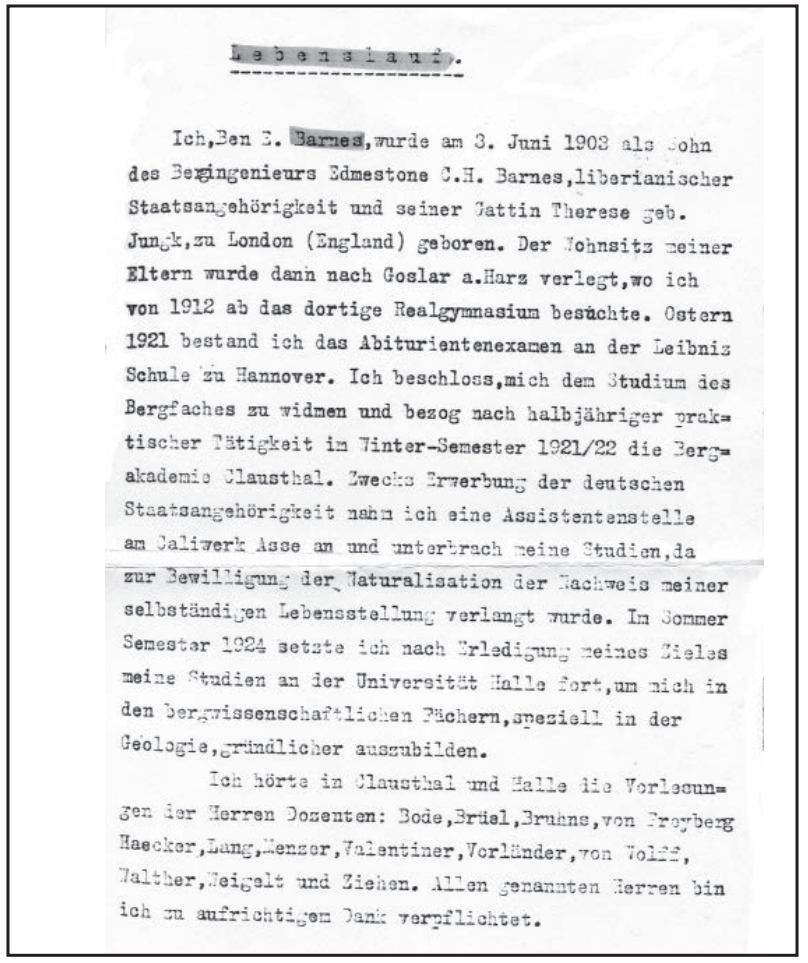

Figure 5 Fotocopy of a type written "curriculum vitae" of Ben E. Barnes, on the occasion of his matriculation at the University of Halle (Saale) in summer 1924 (original document housed in the archive of Halle (Saale) University).

With this publication Barnes qualified for a "Dr." [of natural sciences] being an equivalent for the PhD.

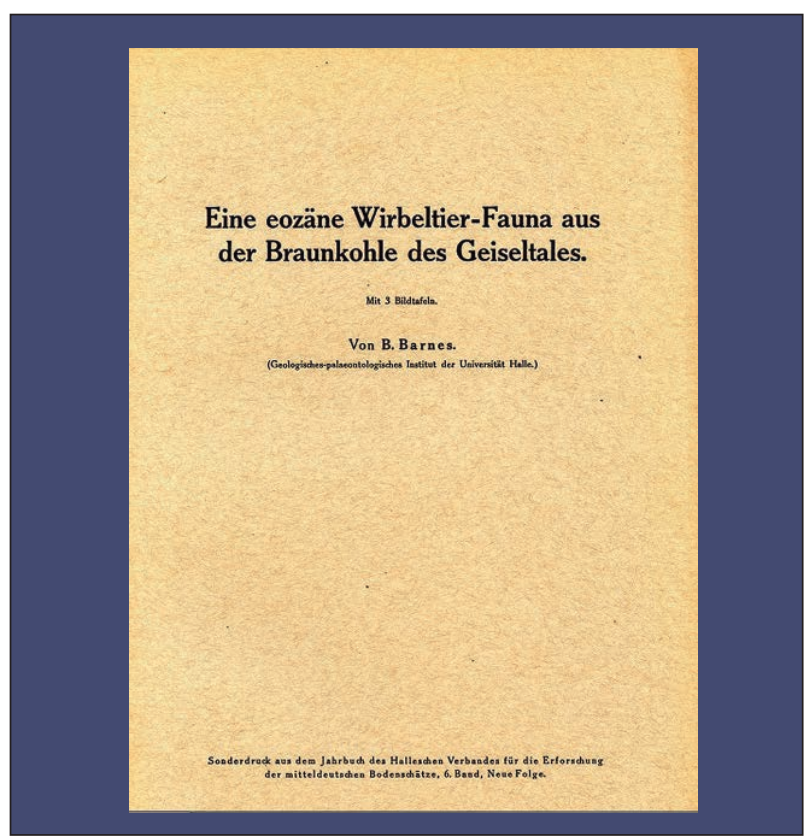

Figure 6 Title page of the first publication, made by Ben Barnes (1927), on findings of vertebrates from the Eocene of the Geiseltal with remarkable figures on the attached tables. The figured fossils are still housed in the Geiseltal collection. 
Looking forward from the late 1920s a lot fossil excavation campaigns took place in a time span up to 1938 and then subsequently after World War II, from 1949 to 1993 . The moving of the productive mining areas in the 1980 s more to the northwestern part of the outcrop led to a minor fossil content, primarily due to poorer geochemical conditions for fossilization.

These numerous consecutive excavations and field campaigns were carried out by an undecided number of excavators, both by prominent scientists and by those we do not know by name.

All of them have in common that they are followers of the renowned Ben Barnes, the pioneer of systematic and quantitative vertebrate excavations in the Geiseltal lignites.

With his successful work, undertaken using with modern scientific aspects of his time, he gave rise for many other researchers to do so in the same way and to contribute step by step in reconstructing the geological and palaeontological history of fauna, flora and palaeoenvironment etc. in the Geiseltal.

Meanwhile, 88 years passed from the date of Barnes's publication. Several hundreds of publications are meanwhile available on various aspects of the Geiseltal Fossillagerstätte.

Interestingly, although we cannot acquire any new material (pits have been abandoned and are covered by a lake meanwhile), fossil research is still ongoing with the housed materials. Scientists from all over the world visit us consistently for their comparative studies.

Due to new developed scientific and technical methods etc., we are optimistic to contribute further results for the completion of our knowledge on this famous fossil site "Fossillagerstätte Geiseltal" in the future.

It is a pity that Ben Barnes passed away already decades ago. I am sure, he would be proud of the developed and long scientific story of the Eocene Geiseltal since the time he gave the decisive initial spark for systematic and quantitative excavation on vertebrates in this brown coal deposit.

\section{References}

Aguilar, J.-P.; Legendre, S. \& Michaux, J. 1997. Actes du Congrès BiochroM'97, Mémoires et Travaux d'Ecole Pratique des Hautes Etude, Institut de Montpellier, 21: 1-818.

Barnes, B. 1927. Eine eozäne Wirbeltier-Fauna aus der
Braunkohle des Geiseltales. Jahrbuch des Halleschen Verbandes für die Erforschung der mitteldeutschen Bodenschätze, 6: 5-24.

Brochu, C.A. 2013. Phylogenetic relationships of Paleogene ziphodont eusuchians and the status of Pristichampsus Gervais, 1853. Earth and Environmental Science, Transactions of the Royal Society of Edinburgh, 103: 1-30.

Erfurt, J. 1995. Taxonomie der eozänen Artiodactyla (Mammalia) des Geiseltales mit besonderer Berücksichtigung der Gattung Ragatherium. Hallesches Jahrbuch für Geowissenschaften, 17: 47-58.

Erfurt, J. 2000. Rekonstruktion des Skelettes und der Biologie von Anthracobunodon weigelti (Artiodactyla, Mammalia) aus dem Eozän des Geiseltales. Hallesches Jahrbuch für Geowissenschaften, 12: 57-141.

Erfurt, J. \& Haubold, H. 1989. Artiodactyla aus den eozänen Braunkohlen des Geiseltales bei Halle (DDR). Palaeovertebrata, 19(3): 131-160.

Franzen, J.L. 1995. Die Equoidea des europäischen Mitteleozäns (Geiseltalium). Hallesches Jahrbuch für Geowissenschaften, 17: 31-45.

Franzen, J.L. 1999. Lophiotherium sondaari n. sp. (Mammalia, Perissodactyla, Equidae) aus der oberen Unterkohle des Geiseltales bei Halle (Saale). DEINSEA, 7: 187-194.

Franzen, J.L. 2006. Eurohippus n. g., a new genus of horses from the Middle to the late Eocene of Europe. Senckenbergiana lethaea, 86(1): 97-102.

Franzen, J.L. \& Haubold, H. 1986a. Revision der Equoidea aus den eozänen Braunkohlen des Geiseltales bei Halle (DDR). Palaeovertebrata, 16(1): 1-34.

Franzen, J.L. \& Haubold, H. 1986b. The Middle Eocene of European mammalian stratigraphy. Definition of the Geiseltalium. Modern Geology, 10: 159-170.

Franzen, J.L. \& Haubold, H. 1987. The biostratigraphic and palaeoecological significance of the Middle Eocene locality Geiseltal near Halle (German Democratic Republic). Münchner Geowissenschaftliche Abhandlungen, 10: 93-100.

Franzen, J.L.; Haubold, H. \& Storch, G. 1993. Relationships of the mammalian faunas from Messel and the Geiseltal. Kaupia, 3: 145-149.

Gallwitz, H. 1955. Kalk, Kieselsäure und Schwefeleisen in der Braunkohle des Geiseltales und ihre Bedeutung für die Fossilisation. Paläontologische Zeitschrift, 29(1/2): 33-37.

Hastings, A. K. \& Hellmund, M. 2015a. Aus der Morgendämmerung: Pferdejagende Krokodile und Riesenvögel. - Gaining Ground: Horse-hunting Crocodiles and Giant Birds. Begleitband zur gleichnamigen Ausstellung in der Nationalen Akademie der Wissenschaften Leopoldina vom 6. März bis 29. Mai 2015 in Halle (Saale), Deutschland. Companion volume to the exhibition presented at the National Academy of Sciences Leopoldina from March 6th to May 29th, 2015 in Halle (Saale), Germany, 120p.

Hastings, A.K. \& Hellmund, M. 2015b. Rare in situ preservation of adult crocodylian with eggs from the Middle Eocene of Geiseltal, Germany: implications for parental care in archosaurs. Palaios, 30(6): 446-461.

Hastings, A. K. \& Hellmund, M. 2015c. Rare in situ preservation of adult crocodilian with eggs from the Middle Eocene Geiseltal Fossillagerstätte, Germany. In: SOCIETY OF VERTEBRATE PALEONTOLOGY MEETING, 75, Dallas, USA, 2015, Abstracts of Papers for the 75th Annual Meeting, SVP, p. 139-140.

Hastings, A.K. \& Hellmund, M. in review. Evidence for prey preference partitioning in the Middle Eocene highdiversity crocodylian assemblage of the Geiseltal Fossillagerstätte, Germany, utilizing skull shape analysis. Geological Magazine.

Haubold, H. 1987. Geiseltalium: ein neues LandsäugetierZeitalter im Paläogen. Hallesches Jahrbuch für Geowissenschaften, 12: 120-121.

Haubold, H. 1989. Die Referenzfauna des Geiseltalium, 
MP Levels 11 bis 13 (Mitteleozän, Lutetium). Palaeovertebrata, 19(3): 81-93.

Haubold, H. 1995. Wirbeltiergrabung und -forschung im Geiseltaleozän. Hallesches Jahrbuch für Geowissenschaften, 17: 1-18.

Haubold, H. \& Hellmund, M. 1997. Contribution of the Geiseltal to the Paleogene Biochronology and the actual perspective of the Geiseltal district. In: AGUILAR, J.P.; LEGENDRE, S. \& MICHAUX, J. (Eds.), Actes $d u$ Congrès BiochroM'97, Mémoires et Travaux d'Ecole Pratique des Hautes Etude, Institut de Montpellier, p. 353-359.

Haubold, H. \& Hellmund, M. 1998a. Das Geiseltalmuseum am Institut für Geologische Wissenschaften, Veröffentlichungen der Akademischen Sammlungen und Museen der Martin-Luther Universität HalleWittenberg. Halle (Saale), Martin-Luther Universität Halle-Wittenberg, 39p.

Haubold, H. \& Hellmund, M. 1998b. The Geiseltalmuseum of the Institute of Geological Sciences, University Halle-Wittenberg. Hallesches Jahrbuch für Geowissenschaften, 6: 11-18.

Haubold, H. \& Krumbiegel, G. 1984. Typenkatalog der Wirbeltiere aus dem Eozän des Geiseltals. 50 Jahre Geiseltalmuseum an der Martin-Luther-Universität Halle - Wittenberg, 1: 1-67.

Haubold, H. \& Thomae, M. 1990. Stratigraphische Revision der Wirbeltierfundstellen des Geiseltaleozäns. Hallesches Jahrbuch für Geowissenschaften, 15: 3-20.

Hellmund, M. 1997. Letzte Grabungsaktivitäten im südwestlichen Geiseltal bei Halle (Sachsen - Anhalt, Deutschland) in den Jahren 1992 und 1993. Hercynia, 30(2): 163-176.

Hellmund, M. 2000. Erstnachweis von Plagiolophus cartieri Stehlin (Palaeotheriidae, Perissodactyla) in der unteren Mittelkohle (uMK, MP12) des Geiseltales bei Halle (Sachsen-Anhalt, Deutschland). Neue Jahrbuch für Geologie und Paläontologie Monatshefte, 2000(4): 205-216.

Hellmund, M. 2001 Magensteine von Crocodiliern in der mitteleozänen Grundmassenkohle des ehemaligen Tagebaues, Mücheln-Westfeld (Geiseltal, SachsenAnhalt, Deutschland). Hallesches Jahrbuch für Geowissenschaften, 13: 77-99.

Hellmund, M. 2004. Smithers Lake in Texas - Johannes Weigelt's Aktuo-Feldlabor für die eozäne Geiseltalforschung. Hallesches Jahrbuch für Geowissenschaften, 26: 135-138.

Hellmund, M. 2005. A three-dimensional skeletal reconstruction of the Middle Eocene Propalaeotherium hassiacum Haupt 1925 (Equidae, Perissodactyla, Mammalia) and a modern synoptic painting of some individuals within their habitat. Kaupia (Darmstädter Beiträge zur Naturgeschichte), 14: 15-20.

Hellmund, M. 2007. Exkursion: Ehemaliges Geiseltalrevier, südwestlich von Halle (Saale). - Aus der Vita des eozänen Geiseltales, In: ERFURT, J. \& MAUL, L.C. (Eds.), Tagung des Arbeitskreises für Wirbeltierpaläontologie der Paläontologischen Gesellschaft, Programm und wissenschaftliche Beiträge, Hallesches Jahrbuch für Geowissenschaften, vol. 23, p. 1-16.

Hellmund, M. 2013a. Odontological and osteological investigations on Propalaeotheriids (Mammalia, Equidae) from the Eocene Geiseltal Fossillagerstätte (Central Germany) - a full range of extraordinary phenomena. Neues Jahrbuch für Geologie und Paläontologie-Abhandlungen, 267(2): 127-154.

Hellmund, M. 2013b. Reappraisal of the bone inventory of Gastornis geiselensis (Fischer 1978) from the Eocene "Geiseltal Fossillagerstätte" (Saxony-Anhalt, Central Germany). Neues Jahrbuch für Geologie und Paläontologie-Abhandlungen, 269(2): 203-220.

Hellmund,M.2013c.DieeozänenUrpferdeausMitteldeutschland, die „Stars" unter den Geiseltalfossilien. In: BECKER, P.-R. \& BEICHLE, U. (Eds.), Pferde Geschichten, vom
Urpferd zum Sportpferd, Schriftenreihe Landesmuseum für Natur und Mensch. Oldenburg, ISENSEE p. 35-54.

Hellmund, M. \& Hastings, A.K. 2014. Messel and Geiseltal. In: SMITH, K.T.; LEHMANN, T.; HELLMUND, M. \& HASTINGS, A.K. (Eds.), Messel and Geiseltal: Highlights from the Cenozoic. Senckenberg world of biodiversity, Martin-Luther-Universität HalleWittenberg, Geiseltalsammlung, Zentralmagazin Naturwissenschaftlicher Sammlungen, p. 25-46.

Hellmund, M. \& Koehn, C. 2000. Skelettrekonstruktion von Propalaeotherium hassiacum (Equidae, Perissodactyla, Mammalia), basierend auf Funden aus dem eozänen Geiseltal (Sachsen-Anhalt, Deutschland). Hallesches Jahrbuch für Geowissenschaften, 12: 1-55.

Hellmund, M. \& Wilde, V. 2001. Das Geiseltal-Projekt 2000: erste wissenschaftliche Ergebnisse. Hallesches Jahrbuch für Geowissenschaften, 13: 1-99.

Hellmund, M., \& Wilde, V. 2009 Der „Mageninhalt“ von Propalaeotherium isselanum aus dem Geiseltal (Sachsen-Anhalt, Deutschland). Hercynia, 42: 167-175.

Hooker, J.J. 2013. Origin and Evolution of the Pseudorhyncocyonidae, a European Paleogene family of insectivorous placental mammals. Palaeontology, 56(4): 807-835.

Hooker, J.J. \& Thomas, K.M. 2001. A new species of Amphiragatherium (Choeropotamidae, Artiodactyla, Mammalia) from the Late Eocene Headon Hill Formation of southern England and phylogeny of endemic European "anthracotherioids". Palaeontology, 44(5): 827-853.

Knochenhauer, G. 1989. Die Geschichte des Braunkohlenbergbaues im Geiseltal. VEB BKW Geiseltal, Technische Kurzinformationen, 25: 20-28.

Koehn, C. \& Hellmund, M. 2001. Zur Skelettrekonstruktion des „Urpferdes“ Propalaeotherium hassiacum Haupt aus dem unteren Mitteleozän Deutschlands. Der Präparator, 47(3): 127-140.

Krumbiegel, G. 1959a. 25 Jahre Geiseltalsammlung (19341959) des Geologisch-Paläontologischen Instituts der Martin-Luther - Universität Halle-Wittenberg - Wissenschaftliche Zeitschrift Universität Halle. MathematischNaturwissenschaftliche, 8(6): 1041-1052.

Krumbiegel, G. 1959b. Die tertiäre Pflanzen- und Tierwelt der Braunkohle des Geiseltales. Wittenberg Lutherstadt, Verlag Ziemsen, 156p.

Krumbiegel, G. 1962. Die Fossilfundstellen der mitteleozänen Braunkohle des Geiseltales. Wissenschaftliche Zeitschrift Universität Halle, MathematischNaturwissenschaftliche, XI(6): 745-762.

Krumbiegel, G. 1977. Genese, Palökologie und Biostratigraphie der Fossilfundstellen im Eozän des Geiseltales. Kongreß und Tagungsberichte der Martin-Luther-Universität Halle-Wittenberg, Wissenschaftliche Beiträge, 1977/2(P5): 113-138.

Krumbiegel, G. \& Hellmund, M. 2012. Zur wissenschaftlichen Entwicklung des Geiseltalmuseums und zu den Geländeaktivitäten im Geiseltalrevier. Mauritiana, 22: 16-42.

Krumbiegel, G., Rüffle, L. \& Haubold, H. 1983. Das eozäne Geiseltal. Neue Brehm Bücherei, Wittenberg Lutherstadt, $227 \mathrm{p}$

Kurz, C. 2002. Die Didelphimorphia und Peradectida aus dem Eozän der Grube Messel und dem Geiseltal: Ökomorphologie, Diversität und Paläogeographie. Unpublished Ph.D. Dissertation, Universität Bonn.

Kurz, C. 2005. Ecomorphology of opossum-like marsupials from the Tertiary of Europe and a comparison with selected taxa. Kaupia (Darmstädter Beiträge zur Naturgeschichte), 14: 21-26.

Lange-Badre, B. \& Haubold, H. 1990. Les Créodontes (Mammifères) du gisement du Geiseltal (Eocène moyen, RDA). Geobios, 23(5): 607-637.

Mayr, G. 2002. Avian Remains from the Middle Eocene of the Geiseltal (Sachsen-Anhalt, Germany). In: ZHONGHE, 
Z. \& FUCHENG, Z. (Eds.), Proceedings of the 5th Symposium of the Society of Avian Paleontology and Evolution. Beijing, Science Press, p. 77-96.

Mayr, G. 2007. Synonymy and actual affinities of the putative Middle Eocene "New World vulture" Eocatharthes Lambrecht, 1935 and "Hornbill" Geiseloceros Lambrecht, 1935 (Aves, Ameghinornithidae). Paläontologische Zeitschrift, 81(4): 457-462.

Mertz, D.F. \& Renne, P.R. 2005. A numerical age for the Messel deposit (UNESCO World Heritage Site) derived from 40Ar/39Ar dating on a basaltic rock fragment. CourierForschungsinstitut-Senckenberg, 255: 67-75.

Morlo, M. 1999. Niche structure and evolution in creodont (Mammalia) faunas of the European and North American Eocene. Geobios, 32(2): 297-305

Morlo, M.; Schaal, S.; Mayr, G. \& Seiffert, C. 2004. An annotated taxonomic list of the Middle Eocene (MP 11) Vertebrata of Messel. Courier-ForschungsinstitutSenckenberg, 252: 95-108.

Müller, J. 2001. Osteology and relationships of Eolacerta robusta, a lizard from the Middle Eocene of Germany (Reptilia, Squamata). Journal of Vertebrate Paleontology, 21(2): 261-278.

Rauhe, M. \& Rossmann, T. 1995. News about fossil crocodiles from the Middle Eocene of Messel and Geiseltal, Germany. Hallesches Jahrbuch für Geowissenschaften, 7: $81-92$.

Rieppel, O.; Conrad, J.L. \& Maisano, J.A. 2007. New morphological data for Eosaniwa koehni Haubold, 1977 and a revised phylogenetic analysis. Journal of Paleontology, 81(4): 760-769.

Rossmann, T. 2000a. Osteologische Beschreibung von Geiseltaliellus longicaudus Kuhn, 1944 (Reptilia, Squamata) aus dem Eozän der Fossillagerstätten Geiseltal und Grube Messel (Deutschland), und eine Revision der Gattung Geiseltaliellus und verwandter Formen. Palaeontographica, 258(4-6): 117-158.

Rossmann, T. 2000b. Skelettanatomische Beschreibung von Pristichampsus rollinatii (Gray) (Crocodilia, Eusuchia) aus dem Paläogen von Europa, Nordamerika und Ostasien. Courier-Forschungsinstitut-Senckenberg, 221: $1-107$

Schmidt-Kittler, N. 1987. International Symposium on Mammalian Biostratigraphy and Paleoecology of the European Paleogene. München, Münchner Geowissenschaftliche Abhandlungen, 312p.

Smith, K.T.; Lehmann, T.; Hellmund, M. \& Hastings, A.K. 2014. Messel and Geiseltal: Highlights from the Cenozoic. Senckenberg world of biodiversity, Martin-Luther-Universität Halle-Wittenberg, Geiseltalsammlung, Zentralmagazin Naturwissenschaftlicher Sammlungen., 46p.

Schwab, M., Hauschke, N. \& Hellmund, M. 2011. Johannes Walther (1860-1937), dem Begründer der Faziesregel und Ordinarius der Martin-Luther-Universität Halle-Wittenberg zum 150. Hallesches Jahrb Geowiss, 32/33: 1-18.

Stanley, S.M. 2001. Historische Geologie. Heidelberg, Spektrum Akademischer Verlag, 710p.

Steinheimer, F.; Hellmund, M.; Schafberg, R. \& Schneider, K. 2012. National wertvolles Kulturgut in Halle /S. unter staatlichem Schutz - Fünf Einzelsammlungen des Zentralmagazins Naturwissenschaftlicher Sammlungen (ZNS) der Martin-Luther-Universität Halle-Wittenberg als national wertvolles Kulturgut eingestuft. Fakultätsbote, Gesellschaft zur Förderung der Agrarund Ernährungswissenschaften an der Martin-LutherUniversität Halle-Wittenberg eingetragener Verein, 1(2012): 8-17.

Steininger, F.F. 1999. Chronostratigraphy, Geochronology and Biochronology of the Miocene "European Land Mammal Mega-Zones" (ELMMZ) and the Miocene "Mammal- Zones (MN-Zones)". In: RÖSSNER, G.E. \& HEISSIG, K. (Eds.), The Miocene Land Mammals of Europe. München, Dr. F. Pfeil, p. 9-24.
Storch, G. 1986. Die Säuger von Messel: Wurzeln auf vielen Kontinenten. Spektrum der Wissenschaften, 6: 48-65.

Storch, G. 1995. Kleinsäugetiere aus dem Geiseltal und Messel im Kontext alttertiärer Faunenentfaltungen. Hallesches Jahrbuch für Geowissenschaften, 17: 59-64.

Thalmann, U. 1994. Die Primaten aus dem eozänen Geiseltal bei Halle/Saale (Deutschland). Courier-ForschungsinstitutSenckenberg, 175: 1-161.

Vetter, H. 1931. Entwicklung und Lagerungsverhältnisse der Grabungen an der älteren Fundstelle der Grube Cecilie im Geiseltale. Kaiserliche Leopoldinische Deutsche Akademie der Naturforscher, 1: 29-35.

Vetter, H. 1932. Entwicklung und Lagerungsverhältnisse der Grabungen an der älteren Fundstelle der Grube Cecilie im Geiseltale. Nova Acta Leopoldina, 1(1): 29-35.

Voigt, E. 1933a Die Lackfilm-Methode, ihre Bedeutung und Anwendung in der Paläontologie, Sedimentpetrographie und Bodenkunde. Zeitschrift der deutschen geologischen Gesellschaft, 88(4): 272-292.

Voigt, E. 1933b. Die Übertragung fossiler Wirbeltierleichen auf Zellulose-Filme, eine neue Bergungsmethode für Wirbeltiere aus der Braunkohle. Paläontologische Zeitschrift, 15: 72-78

Voigt, E. 1934. Die Fische aus der mitteleozänen Braunkohle des Geiseltales. Nova Acta Leopoldina, 2: 22-142.

Voigt, E. 1936. Weichteile an Säugetieren aus der eozänen Braunkohle des Geiseltales. Nova Acta Leopoldina, 4: 301-310.

Voigt, E. 1988. Preservation of Soft Tissues in the Eocene Lignite of the Geiseltal near Halle/S. CourierForschungsinstitut-Senckenberg, 107: 325-343.

Walther, J. \& Weigelt, J. 1932. Die eozäne Lebewelt in der Braunkohle des Geiseltals. Nova Acta Leopoldina, 1(1): 1-27.

Weigelt, J. 1927. Rezente Wirbeltierleichen und ihre paläobiologische Bedeutung. Leipzig, M. Weg, 227p.

Weigelt, J. 1931. Über ein Leichenfeld in der Mittelkohle der Braunkohlengrube Cecilie im Geiseltal (Mitteleozän). Palaeobiologica, 4: 49-78.

Weigelt, J. 1933. Die Biostratinomie der 1932 auf der Grube Cecilie im mittleren Geiseltal ausgegrabenen Leichenfelder. Nova Acta Leopoldina, 1: 157-174.

Weigelt, J. 1934. Die Geiseltalgrabungen des Jahres 1933 und die Biostratinomie der Fundschichten. Nova Acta Leopoldina, 1: 552-600.

Weigelt, J. 1935. Some Remarks on the Excavations in the Geisel Valley. Quarterly Review of German Science, 1(4): $155-159$

Weigelt, J. 1989. Recent Vertebrate carcasses and their paleobiological implications. Chicago, University of Chicago Press, 188p.

Wilde, V. 1995. Die Makroflora aus dem Mitteleozän des Geiseltalgebietes, kurze Übersicht und Vergleiche. Hallesches Jahrbuch für Geowissenschaften, 17: 121-138.

Wilde, V. 2001. Ein Farnhorizont aus dem Mitteleozän des Geiseltales (Sachsen-Anhalt, Germany). Hallesches Jahrbuch für Geowissenschaften, 13: 69-75.

Wilde, V. \& Hellmund, M. 2006. Neue Geländearbeiten im ehemaligen Braunkohlenrevier Geiseltal. Aspekte der Kooperation zwischen dem Forschungsinstitut Senckenberg in Frankfurt (Main) und dem Geiseltalmuseum am Institut für Geologische Wissenschaften in Halle (Saale). Natur und Museum, 136(7/8): 162-173.

Wilde, V. \& Hellmund, M. 2010. First record of gut contents from a middle Eocene equid from the Geiseltal near Halle (Saale), Sachsen-Anhalt, Central Germany. Palaeobiodiversity and Palaeoenvironments, 90(2): 153-162.

Wilde, V. \& Riegel, W. 2010. "Affenhaar" revisited - Facies context of in situ preserved latex from the Middle Eocene of Central Germany. International Journal of Coal Geology, 83(2-3): 182-194. 